\title{
ANALISIS DAYA SAING USAHATANI KAPAS RAKYAT DI SULAWESI SELATAN
}

\author{
Junaedi $^{1)}$, Masyhuri ${ }^{2)}$, Slamet Hartono ${ }^{2)}$, Dwidjono Hadi Darwanto ${ }^{2)}$ \\ 1) Politeknik Pertanian Negeri Pangkep \\ ${ }^{2}$ ) Fakultas Pertanian UGM
}

\begin{abstract}
This study aims to determine the impact of policy Cotton Communities Development Acceleration Programme in South Sulawesi. This study was conducted in Bulukumba, Bone and Soppeng. The sampling method used was multistage sampling with purposive sub-district and village levels. Samples taken by cotton farmers random sampling as many as 150 farmers. Analysis of the data using the Policy Analysis Matrix (PAM). The results showed that people who cultivated cotton farming with the input and output subsidies the farmer is able to provide a competitive advantage $(\mathrm{PCR}$ value $=0.77$ ) and comparative advantage $($ DCRC value $=0.33)$.
\end{abstract}

Key Words : Competitiveness, Cotton, PAM

\begin{abstract}
ABSTRAK
Penelitian ini bertujuan untuk mengetahui dampak kebijakan Program Akselerasi Pengembangan Kapas Rakyat di Sulawesi Selatan. Penelitian ini dilaksanakan di Kabupaten Bulukumba, Bone dan Soppeng. Metode sampling yang yang digunakan adalah multistage sampling dengan cara purposive pada tingkat kecamatan dan desa. Sampel petani kapas diambil secara random sampling sebanyak 150 petani. Analisis data menggunakan Policy Analysis Matrix (PAM). Hasil penelitian menunjukkan bahwa usahatani kapas rakyat yang diusahakan dengan adanya subsidi input dan output ditingkat petani mampu memberikan keuntungan kompetitif (nilai $\mathrm{PCR}=0,77$ ) dan keunggulan komparatif (nilai DCRC $=0,33$ ).
\end{abstract}

Kata Kunci : Daya Saing, Kapas, PAM

\section{PENDAHULUAN}

Pemerintah saat ini terus berusaha meningkatkan kontribusi kapas produksi dalam negeri pada industri TPT Nasional sekaligus terus mengurangi ketergantungan impor kapas, salah satunya dengan terus berupaya melakukan percepatan (akeselerasi) peningkatan luas areal dan produksi kapas melalui Program Akselerasi Pengembangan Kapas. Guna mendukung pengembangan kapas di Indonesia maka pemerintah melalui program akselerasi tahun 2011 
menargetkan pengembangan kapas dari masing-masing provinsi wilayah pengembangan kapas seluas 15.900 ha, mencakup : Provinsi Jawa Tengah 1.000 ha, Provinsi Jawa Timur 2.050 ha, DIY 750 ha, Provinsi Bali 800 ha, Provinsi NTB 800 ha dan Provinsi NTT 3.500 ha dan Provinsi Sulawesi Selatan 7.000 ha (Ditjenbun, 2010).

Program akselerasi pengembangan kapas adalah sebagai upaya percepatan peningkatan produksi kapas dalam rangka meningkatkan pemenuhan kebutuhan serat kapas sebagai bahan baku industri tekstil dalam negeri sampai dengan $5 \%$ pada tahun 2014. Dukungan perusahaan pengelola yang diharapkan antara lain; optimalisasi ginnery, fasilitasi kredit perbankan (sebagai avalis), pembangunan kebun benih kapas unggul dan penampungan hasil. Sulsel diharapkan mampu mendongkrak pengembangan produksi komoditas kapas untuk memenuhi permintaan kebutuhan kapas yang merupakan bahan baku tekstil. Untuk memacu pengembangan tersebut, Sulsel pada tahun 2011 mengimpor benih kapas dari China sebanyak 25.896 ton. Benih tersebut merupakan varietas unggul baru jenis HSC 138 dan HSC 188 dengan keunggulan yang terletak pada potensi produksinya yang bagus serta tidak rentan terhadap serangan hama ulat. Penetapan sumber benih kapas sesuai SK Dirjen Perkebunan No. 40/Kpts/SR.120/02/2010, Februari 2010.

Sementara untuk meningkatkan minat petani menanam kapas, pemerintah memberi subsidi benih dan pupuk, serta mematok harga pembelian oleh pengusaha dari petani sebesar Rp 4.000/ kg. Sebelumnya, kapas dari petani hanya dihargai Rp 2.500/ kg. Selain pengembangan demplot, pemerintah provinsi juga mendapatkan alokasi dana dari pemerintah pusat sebesar Rp 1,8 juta rupiah per hektarnya. Dana tersebut akan dialokasikan untuk penyediaan bibit bagi petani kapas yang ada di Sulsel. Kebijakan tersebut diharapkan mampu mendorong perluasan penanaman kapas sekaligus meningkatkan produksi yang diharapkan memberi kontribusi terhadap pemenuhan kebutuhan industri tekstil nasional. Secara umum penelitian bertujuan untuk menganalisis keungulan kompetitif dan komparatif usahatani kapas rakyat di Sulawesi Selatan. 


\section{METODE PENELITIAN}

Penelitian dilaksanakan di Sulawesi Selatan atas dasar bahwa potensi produksi terbesar dihasilkan di provinsi tersebut yakni sebesar 48 persen dari produksi nasional (Ditjenbun, 2010). Dari provinsi terpilih selanjutnya ditentukan lokasi penelitian dengan menggunakan teknik multistage sampling, dengan cara purposive pada tingkat kabupaten, kecamatan dan desa yang merupakan sentra produksi kapas di Sulawesi Selatan. Lokasi penelitian sebagai sentra produksi adalah Kabupaten Bulukumba, Bone dan Soppeng.

Data primer diperoleh dari petani kapas melalui pengamatan langsung di lapangan dengan teknik wawancara melalui pengisian daftar pertanyaan/kuesioner yang telah dipersiapkan. Sampel petani kapas ditentukan secara random sampling, dengan mengambil sebanyak 150 petani sampel yang didistribusi pada masingmasing kabupaten berdasarkan jumlah petani pada masing-masing lokasi/desa sampel.

Analisis daya saing untuk menganalisis sejauh mana daya saing pada usatahani kapas, dilakukan melalui pendekatan terhadap penggunaan sumberdaya domestik dan input tradable. Metode analisis yang digunakan adalah Policy Analysis Matrix (PAM) yang merupakan alat analisis yang digunakan untuk mengetahui efisiensi ekonomi dan besarnya insentif atau dampak intervensi dalam pengusahaan berbagai aktivitas usahatani secara keseluruhan dan sistematis (Monke dan Pearson, 1995).

Pada dasarnya langkah penyusunan Matriks Analisis Kebijakan (Policy Analysis Matrix, PAM) terdiri dari empat tahapan (Pearson, et al 2004). Berikut adalah tahapan yang dilakukan untuk menganalisa daya saing usahatani kapas pada penelitian ini;

1. Penentuan input-output fisik secara lengkap dari aktivitas ekonomi yang dianalisis;

2. Penaksiran harga bayangan (shadow price) dari input dan output;

3. Pemisahan seluruh biaya ke dalam komponen domestik dan asing, serta menghitung besarnya penerimaan; dan 
4. Menghitung dan menganalisis berbagai indikator yang dihasilkan analisis PAM, sebagaimana disajikan dalam tabel analisis di bawah ini.

Penyusunan matrik PAM dilakukan dengan menggunakan struktur inputoutput di tingkat usahatani, dan pelaku tataniaga. Dengan perhitungan ini dapat diperoleh keuntungan baik finansial maupun ekonomi. Dampak kebijakan pemerintah yang diterapkan baik kepada input, output maupun input dan output secara bersama dapat diketahui.

Analisis ekonomi yang dilakukan didasarkan pada harga harga sosial atau harga bayangan, karena harga pasar tidak mencerminkan biaya imbangan idialnya dan tidak mencerminkan korbanan yang dikeluarkan jika sumberdaya tersebut dipakai untuk kegiatan lain. Harga bayangan dilakukan dengan cara menyesuaikan terhadap penyimpangan harga yang terjadi akibat kebijakan pemerintah (subsidi, pajak, tarif, kebijakan harga) maupun distorsi pasar.

Harga bayangan output adalah harga output yang terjadi di pasar dunia apabila diberlakukan pasar bebas dan harga yang digunakan adalah harga batas order price). Harga bayangan output untuk komoditas ekspor atau berpotensi ekspor digunakan harga perbatasan FOB. Sedangkan harga bayangan output untuk komoditas impor digunakan harga perbatasan CIF. Penelitian ini dalam menghitung harga bayangan kapas menggunakan harga CIF karena volume ekspor kapas lebih rendah dibandingkan volume impornya. Harga CIF ini akan dikonversi dengan SER dan dikurangi biaya tataniaga berupa transportasi dan Handling dari pelabuhan ke lokasi penelitian.

Perhitungan harga bayangan input yang tradable sama dengan perhitungan harga bayangan output, yaitu dengan menggunakan harga perbatasan (border price), yaitu komoditi ekpor menggunakan harga FOB dan komoditi impor menggunakan CIF. Sedangkan untuk perhitungan harga bayangan input yang non tradable digunakan harga domestik.

Penentuan harga bayangan tenaga kerja pada usahatani kapas di lokasi penelitian mengacu pada pada pernyataan Pearson, (1987) bahwa harga sosial untuk tenaga kerja diestimasi dengan prinsip social opportunity cost. Karena 
faktor sumberdaya domestik tidak diperdagangkan secara internasional, maka faktor tersebut tidak ada harga dunianya. Sehingga dapat disimpulkan bahwa social opportunity cost untuk tenaga kerja yang menganggur adalah nol. Dalam penelitian ini faktor tenaga kerja di klasifikasikan menurut gender, yakni pria dan wanita.

Harga bayangan nilai tukar rupiah didasarkan atas perkembangan nilai tukar dollar pada tahuan 2011, menggunakan rumus yang telah diformulsikan oleh Squire dan Van Der Tak dalam Gittinger (1986) yaitu :

$$
S E R_{2011}=\frac{O E R_{2011}}{S C F_{2011}}
$$

Keterangan :

$\mathrm{SER}_{2011}=$ Shadow exchange rate (nilai tukar bayangan) tahun 2011

$\mathrm{OER}_{2011}=$ Official exchange rate (nilai tukar resmi) tahun 2011

$\mathrm{SCF}_{2011}=$ Standart conversion factor (faktor konversi standar) tahun 2011

Nilai faktor konversi standar yang merupakan rasio dari nilai impor dan ekspor ditambah pajaknya dapat ditentukan sebagai berikut.

$$
S C F t=\frac{M t+X t}{(M t+T m))+(X t-T x)}
$$

Keterangan :

SCFt : Faktor Konversi Standar untuk tahun ke-t

$\mathrm{Xt} \quad$ : Nilai Ekspor Indonesia untuk tahun ke-t (Rp)

Mt : Nilai Impor Indonesia untuk tahun ke-t (Rp)

Txt : Penerimaan Pemerintah dari pajak ekpor untuk tahun ke-t (Rp)

Tmt : Penerimaan Pemerintah dari pajak impor untuk tahun ke-t (Rp)

Hasil analisis PAM akan memberikan informasi tentang profitabilitas daya saing (keunggulan kompetitif), efisiensi ekonomik (keunggulan komparatif) suatu komoditas, dalam hal ini adalah usahatani kapas. Matriks Analisis Kebijakan (Policy Analysis Matrix, PAM) disajikan pada Tabel 1. 
Tabel 1. Formulasi Model Policy Analysis Matrix (PAM)

\begin{tabular}{|c|c|c|c|c|}
\hline \multirow[b]{2}{*}{ Komponen } & \multirow[b]{2}{*}{ Penerimaan } & \multicolumn{2}{|c|}{ Biaya } & \multirow[b]{2}{*}{ Keuntungan } \\
\hline & & $\begin{array}{c}\text { Input } \\
\text { tradable }\end{array}$ & $\begin{array}{c}\text { Faktor } \\
\text { domestik }\end{array}$ & \\
\hline Harga privat & $\mathrm{A}$ & $\mathrm{B}$ & $\mathrm{C}$ & $\mathrm{D}$ \\
\hline Harga sosial & $\mathrm{E}$ & $\mathrm{F}$ & $\mathrm{G}$ & $\mathrm{H}$ \\
\hline Dampak Divergensi & I & $\mathrm{J}$ & $\mathrm{K}$ & $\mathrm{L}$ \\
\hline
\end{tabular}

Sumber : Monke and Pearson (1995)

Keterangan:

$\mathrm{I}=\mathrm{A}-\mathrm{E} ; \quad \mathrm{J}=\mathrm{B}-\mathrm{F} ; \quad \mathrm{K}=\mathrm{C}-\mathrm{G} ; \quad \mathrm{L}=\mathrm{D}-\mathrm{H} . \quad \mathrm{D}=\mathrm{A}-(\mathrm{B}+\mathrm{C}) ; \mathrm{H}=\mathrm{E}-(\mathrm{F}+\mathrm{G}) ;$

$\mathrm{L}=\mathrm{I}-(\mathrm{J}+\mathrm{K}) ; \mathbf{P C R}=\mathrm{C} /(\mathrm{A}-\mathrm{B}) ; \mathbf{D R C R}=\mathrm{G} /(\mathrm{E}-\mathrm{F}) ; \mathrm{OT}=\mathrm{A}-\mathrm{E} ; \mathrm{NPCO}=\mathrm{A} / \mathrm{E}$;

$\mathrm{IT}=\mathrm{B}-\mathrm{F} ; \mathrm{NPCI}=\mathrm{B} / \mathrm{F} ; \mathrm{FT}=\mathrm{C}-\mathrm{G} ; \mathrm{EPC}=(\mathrm{A}-\mathrm{B}) /(\mathrm{E}-\mathrm{F}) ; \mathrm{NT}=\mathrm{D}-\mathrm{H} ;$

$\mathrm{PC}=\mathrm{D} / \mathrm{H} ; \mathrm{SRP}=\mathrm{L} / \mathrm{E} \quad$ (Arti singkatan lihat uraian di bawah)

Berdasarkan data pada tabel PAM di atas, kemudian dapat dianalisis dengan berbagai indikator sebagai berikut:

(1) Analisis Keuntungan atau Private Profitability $(\mathrm{PP}): \mathrm{D}=\mathrm{A}-(\mathrm{B}+\mathrm{C})$;

(2) Analisis keuntungan sosial atau Social Profitability (SP) : H $=\mathrm{E}-(\mathrm{F}+\mathrm{G})$;

(3) Efisiensi Finansial (Keunggulan Kompetitif) dengan indikator Private Cost Ratio $: \mathrm{PCR}=\mathrm{C} /(\mathrm{A}-\mathrm{B})$;

(4) Analisis efisiensi ekonomik atau keunggulan komparatif dengan indikator Domestic Resource Cost Ratio : DRCR = G / (E-F);

(5) Output Transfer : OT = A - E;

(6) Nominal Protection Coefficient on Tradable Output: NPCO = A / E;

(7) Transfer Input : IT = B - F;

(8) Nominal Protection Coefficient on Tradable Input : NPCI = B / F;

(9) Transfer faktor: $\mathrm{TF}=\mathrm{C}-\mathrm{G}$;

(10) Effective Protection Coefficient : $\mathrm{EPC}=(\mathrm{A}-\mathrm{B}) /(\mathrm{E}-\mathrm{F})$;

(11) Transfer Bersih : NT = D - H;

(12) Profitability Coefficient $\mathrm{L} \mathrm{PC}=\mathrm{D} / \mathrm{H}$; dan

(13) Subsidy Ratio to Producer : SRP = L / E.

Nilai PCR menunjukkan berapa banyak sistem produksi usahatani kapas dapat menghasilkan untuk membayar semua faktor domestik yang digunakan, dan tetap dalam kondisi kompetitif. Keuntungan maksimal akan diperoleh jika sistem produksi usahatani kapas mampu meminimumkan nilai PCR. Nilai PCR merupakan kriteria keunggulan kompetitif dari usahatani kapas. Apabila nilai 
PCR $<1$ dan makin kecil, maka aktivitas ekonomi efisien secara finansial. Keunggulan kompetitif adalah alat untuk mengukur keuntungan privat (private profitability) dan dihitung berdasarkan harga pasar dan nilai tukar uang resmi.

Nilai DRCR merupakan salah satu kriteria kemampuan usahatani kapas dalam membiayai faktor domestik pada harga bayangannya atau kriteria dari efisiensi ekonomi relatif dari suatu sistem produksi. Jika DRCR $<1$ dan nilainya makin kecil, berarti sistem produksi usahatani kapas makin efisien dan memiliki daya saing di pasar dunia sehingga dinilai memiliki peluang ekspor yang makin besar. Nilai DRCR merupakan kriteria keunggulan komparatif dari usahatani kapas. Keunggulan komparatif adalah kemampuan suatu wilayah atau negara dalam memproduksi satu unit dari beberapa komoditas dengan biaya yang relatif lebih rendah daripada biaya imbangan sosialnya dari alternatif lainnya.

\section{HASIL DAN PEMBAHASAN}

Akselerasi Pengembangan Kapas Rakyat yang dilakukan di Sulawesi Selatan sebagaimana dijelaskan pada bagian awal penelitian ini bertujuan untuk mempercepat perluasan areal dan peningkatan produksi melalui pemberian bantuan berupa $100 \%$ benih dan $25 \%$ sarana produksi lainnya. Berdasarkan ketentuan pemerintah, besarnya bantuan input fisik yang diberikan untuk per hektar adalah : benih kapas $6 \mathrm{~kg}$, Urea $50 \mathrm{~kg}$, SP $3650 \mathrm{~kg}$, NPK $50 \mathrm{~kg}$, ZA 50 $\mathrm{kg}$, herbisida 2 liter dan insektisida (padat) 100 gram.

Kebijakan pemerintah berdampak positif jika kebijakan bisa membantu produsen dalam negeri meningkatkan keuntungan dengan bisa memasarkan produknya untuk diekspor dan berdampak negatif jika kebijakan tersebut menghambat usahatani suatu komoditi. Indikator kebijakan usatahatani kapas di Sulawesi Selatan bisa dibagi menjadi tiga yaitu dampak kebijakan terhadap output, input dan input-output. Hasil analisis PAM terhadap dampak adanya subsidi input diuraikan pada tabel dibawah ini. 
Tabel 2. Matriks Analisis Kebijakan Usahatani Kapas Rakyat di Sulawesi Selatan Tahun 2011 (Rp/ha)

\begin{tabular}{lrrrr}
\hline \multirow{2}{*}{ Uraian } & Penerimaan & \multicolumn{2}{c}{ Biaya Input } & \\
\cline { 3 - 4 } & & Tradable & $\begin{array}{c}\text { Non } \\
\text { Tradable }\end{array}$ & Keuntungan \\
\hline Harga Privat & 2.703 .000 & 370.238 & 1.806 .367 & 526.395 \\
Harga Sosial & 5.925 .726 & 693.320 & 1.743 .967 & 3.488 .440 \\
Dampak kebijakan & -3.222 .726 & -323.081 & 62.400 & -2.962 .045 \\
\hline
\end{tabular}

Sumber : Analisis Data Primer, 2012

Analisis daya saing kapas rakyat di Sulsel dapat dilihat pada indikator daya saing berikut ini.

Tabel 3. Indikator-Indikator Analisis PAM Usahatani Kapas Rakyat di Sulawesi Selatan, 2011

\begin{tabular}{lr}
\hline \multicolumn{1}{c}{ Indikator } & \multicolumn{1}{c}{ Nilai } \\
\hline Keuntungan Privat (PP) & 526.395 \\
Rasio Biaya Privat (PCR) & 0,77 \\
Keuntungan Sosial (SP) & 3.488 .440 \\
Rasio Sumberdaya Domestik (DRCR) & 0,33 \\
Transfer Output (OT) & -3.222 .726 \\
Koefisien Proteksi Output Nominal (NPCO) & 0,46 \\
Transfer Input (IT) & -323.081 \\
Transfer faktor (FT) & 62.400 \\
Koefisien Proteksi Input Nominal (NPCI) & 0,53 \\
Koefisien Proteksi Efektif (EPC) & 0,45 \\
Transfer Bersih (NT) & -2.962 .045 \\
Koefisien Keuntungan (PC) & 0,15 \\
Rasio Subsidi bagi (SRP) & $-0,50$ \\
\hline Si
\end{tabular}

Sumber : Analisi Data Primer, 2012

\section{a. Analisis Daya Saing}

\section{Analisis Keunggulan Kompetitif}

Keunggulan kompetitif suatu komoditas dapat dilihat berdasarkan indikator-indikator Keuntungan Privat (PP) dan Rasio Biaya Privat (PCR). Indikator tersebut menunjukkan tingkat keuntungan secara finansial dan tingkat efisiensi penggunaan sumberdaya. Nilai PP yang diperoleh dari perhitungan nilai tersebut adalah $\mathrm{Rp} 526.395$ dan PCR 0,77.

Nilai keuntungan privat yang positif $(\mathrm{PP}>0)$ menunjukkan bahwa secara finansial usahatani kapas di Sulsel menguntungkan. Tingkat efisiensi 
alokasi sumberdaya dapat diukur dengan menggunakan Rasio Biaya Privat (PCR) yang merupakan rasio antara biaya faktor domestik dengan selisih antara penerimaan dan biaya input tradable pada harga privat. Nilai PCR menunjukkan bahwa setiap 1 dollar US yang diperoleh dari ekspor kapas dibutuhkan biaya input domestik yang lebih kecil, yakni sebesar 0,77 Dengan nilai PCR kurang dari satu $(\mathrm{PCR}<1)$ maka usahatani kapas telah efisien secara finansial dan memiliki keunggulan kompetitif, dimana petani mampu membiayai faktor domestiknya pada harga privat.

\section{Analisis Keunggulan Komparatif}

Keunggulan komparatif dengan menggunakan nilai Keuntungan Sosial (SP) dan Rasio Biaya Domestik (DRCR). Keuntungan Sosial (SP) diperoleh dari selisih penerimaan Rp. 5.925.726 per kilogram dengan biaya input tradable sebesar Rp 693.320 dan biaya input domestik sebesar Rp 1.743.967 sehingga diperoleh keuntungan Rp 3.488.440. Keuntungan Sosial yang positif $(\mathrm{SP}>0)$ menunjukkan bahwa usahatani kapas menguntungkan secara ekonomi dan layak untuk diusahakan. Indikator DRCR yang merupakan rasio antara biaya domestik dengan selisih penerimaan dikurangi biaya asing pada harga bayangan. Nilai DRCR yang diperoleh adalah 0.33 . Hal ini mengindikasikan bahwa usahatani kapas efisien secara ekonomi dan memiliki keunggulan komparatif (daya saing).

\section{b. Analisis Dampak Kebijakan Pemerintah Terhadap Output}

Kebijakan pemerintah terhadap output bisa dilihat dari dua nilai yaitu Transfer Output (OT) dan Koefisien Proteksi Output Nasional (NPCO). Transfer Output (OT) adalah selisih dari penerimaan privat dan penerimaan sosial. Nilai OT yang diperoleh adalah negatif $(\mathrm{OT}<0)$ yaitu Rp 3.222.726 yang mengindikasikan bahwa tidak ada insentif konsumen terhadap produsen. sehingga harga yang dibayarkan oleh konsumen lebih rendah dari seharusnya sehingga terjadi transfer output dari produsen ke konsumen. Dengan kata lain. tidak ada subsidi output yang menyebabkan harga sosial lebih tinggi daripada harga privat. Harga kapas domestik yaitu Rp 4.250,00 sedangkan harga dunia sebesar $\mathrm{Rp}$ 9.317,18. Perbedaan harga tersebut 
menjadikan penerimaan produsen menjadi lebih rendah pada saat ada kebijakan pemerintah (harga aktual).

Indikator lain yang bisa digunakan untuk melihat dampak kebijakan pemerintah yaitu Koefisien Proteksi Output Nominal (NPCO) yang menunjukkan tingkat proteksi pemerintah terhadap output. Nilai NPCO yang diperoleh yaitu 0,46 yang mengindikasikan bahwa ada hambatan kebijakan pemerintah untuk melakukan ekspor.

Petani hanya memperoleh 46 persen dari harga yang seharusnya yang menyebabkan petani tidak memperoleh insentif untuk meningkatkan produksi. Dengan tidak adanya transfer output dari konsumen ke produsen maka menyebabkan harga yang diterima oleh konsumen lebih rendah dari yang seharusnya dan terjadi kebijakan pemerintah yang melindungi konsumen domestik.

\section{c. Analisis Dampak Kebijakan Pemerintah Terhadap Input}

Kebijakan pemerintah terhadap input bisa berupa subsidi dan hambatan impor untuk melindungi produsen. Untuk mengetahui adanya insentif pemerintah terhadap input bisa dilihat dari indikator Transfer Input (IT). Transfer Faktor (FT) dan Koefisien Proteksi Input Nasional (NPCI).

Nilai Transfer Input (IT) merupakan selisih Biaya Input Tradable Privat dan Sosial. Jika nilai IT positif (IT $>0$ ). maka harga sosial input asing lebih tinggi dan produsen membayar lebih mahal. Nilai IT yang diperoleh untuk petani di Sulsel negatif yaitu Rp 323.081 menunjukkan adanya subsidi pemerintah terhadap input asing. sehingga produsen tidak membayar penuh untuk membeli input.

Transfer Faktor (FT) menunjukkan besarnya subsidi terhadap input non tradable dan diperoleh dari selisih biaya input non tradable privat dan sosial. Jika nilai FT positif (FT $>0$ ) maka terjadi subsidi negatif dan nilai FT negatif $($ FT < 0) maka terjadi subsidi positif. Nilai yang diperoleh yaitu Rp. 55.843,00 per kilogram mengindikasikan bahwa terjadi subsidi negatif dari pemerintah.

Koefisien proteksi input nominal (NPCI) adalah rasio dari biaya input 
tradable privat dan sosial dan merupakan indikator yang menunjukkan tingkat proteksi pemerintah terhadap harga input domestik. Dari hasil yang didapat NPCI kurang dari satu $(\mathrm{NPCI}<1)$ yaitu 0,54 . Kebijakan pemerintah bersifat protektif terhadap input asing dan produsen menerima subsidi atas input asing sehingga produsen membeli dengan harga yang lebih murah. Petani kapas menerima harga input yang lebih murah sebesar 54 persen dari yang seharusnya.

\section{d. Analisis Dampak Kebijakan Pemerintah Terhadap Input-Output}

Kebijakan terhadap input dan output merupakan gabungan antara kebijakan input dan kebijakan output. Indikator dampak kebijakan inputoutput bisa dilihat dari Koefisien proteksi efektif (EPC). Nilai rasio subsidi bagi produsen (SRP). koefisien keuntungan (PC) dan Transfer bersih (NT).

Koefisien Proteksi Efektif (EPC) adalah rasio antara penerimaan privat dikurangi biaya input tradable dengan penerimaan sosial dikurangi biaya input tradable dan menggambarkan sejauh mana kebijakan pemerintah melindungi atau menghambat produksi domestik. Nilai EPC yang diperoleh yaitu 0,43 (EPC $<1)$ menggambarkan kebijakan terhadap output maupun subsidi input bersifat menghambat (tidak efektif) dan tidak memberikan insentif terhadap petani untuk berproduksi.

Transfer bersih (NT) merupakan selisih antara keuntungan Privat dan keuntungan sosial (asumsi pasar persaingan sempurna) yang menggambarkan dampak kebijakan pemerintah terhadap penerimaan. Nilai NT yang diperoleh bernilai negatif yaitu Rp 2.650.129 menunjukkan bahwa kebijakan pemerintah tidak memberikan insentif untuk meningkatkan produksi.

Pengaruh kebijakan secara keseluruhan dicerminkan oleh Koefisien Keuntungan (PC) yang menyebabkan keuntungan privat berbeda dengan keuntungan sosial dan diperoleh dari rasio penerimaan privat dengan sosial. Nilai PC yang diperoleh yaitu 0.15 yang mengindikasikan bahwa keuntungan yang diperoleh petani hanya 15 persen dan kehilangan 85 persen keuntungan yang seharusnya diperoleh. 


\section{KESIMPULAN DAN IMPLIKASI KEBIJAKAN}

\section{Kesimpulan}

Berdasarkan hasil penelitian, dapat diambil kesimpulan bahwa usahatani kapas yang diusahakan melalui Program Akselerasi Pengambangan Kapas Rakyat melalui subsidi input dan output, memiliki keunggulan kompetitif, dengan nilai PCR $0,77(<1)$ dan secara finansial menguntungkan dengan nilai Keuntungan Privat (KP) Rp 526.395. Indikator keunggulan komparatif usahatani kapas juga menunjukkan adanya keunggulan komparatif, dengan nilai DRCR 0,33 $(<1)$. Keuntungan Sosial (KS) yang diperoleh sebesar Rp 3.488.400.

\section{Implikasi Kebijakan}

Guna mendorong peningkatan daya saing, sekaligus minat petani dalam usahataninya. Subsidi input secara fisik, masih terus diperlukan. Namun pada saat yang bersamaan, perlu diperketat mekanisme kontrol di petani. Hal ini dapat dilakukan dengan membuat khusus Prosedur Standar Operasioanal, tentang bagaimana petani dalam memanfaatkan input yang telah diberikan serta bagaimana mengelola kapas sebagai bagian dari industri rumah tangga petani sendiri. Saat ini terdapat petugas lapangan yang bisa diberdayakan membuat monitoring kegiatan petani dilapangan.

Tidak kalah pentingnya, bahkan yang utama. kualitas input harus bisa meyakinkan petani bahwa input yang diberikan memang mampu berkontribusi bagi peningkatan produksi usahatani kapas. Misalnya, benih yang diberikan harus telah diujikan ditingkat lokal, sehingga dapat membangun kepercayaan petani dalam mengelola usahataninya dengan lebih baik.

\section{DAFTAR PUSTAKA}

Direktorat Jenderal Perkebunan, 2009. Pedoman Umum Pelaksanaan Program Peningkatan Produksi Tanaman Serat tahun 2010. Departemen Pertanian, Jakarta.

Direktorat Jenderal Perkebunan. 2010. Akselerasi Pengembangan Kapas. Pertemuan Koordinasi Persiapan Pelaksanaan Pengembangan Tanaman Serat Tahun 2010. Departemen Pertanian. Jakarta

Gittinger JP. 1986. Analisa Ekonomi Proyek-Proyek Pertanian. Jakarta: Universitas Indonesia Press. 
Monke, E.A. and S.R. Person, 1995. The Policy Analysis Matrix for Agricultural Development. Cornel University Press. Ithaca and London.

Pearson S. C. Gotsch, S. Bahri. 2004. Applications of The Policy Analysis Matrix In Indonesian Agriculture. Development Alternatives Inc. - Food Policy Support Activity (DAI - FPSA) Indonesia in Collaboration with Yayasan Obor Indonesia. Jakarta

Pearson S. R. (1987). Net Social Profitability Domestic Resource Cost and Effective Rate of Protection. Journal of Development study.

Pusat Data dan Informasi Pertanian, 2009. Outlook Komoditas Pertanian (Perkebunan). Departemen Pertanian, Jakarta. 